\title{
Interview Scheduling Strategies of New Ph.D. Economists
}

\author{
John A. List
}

To cite this article: John A. List (2000) Interview Scheduling Strategies of New Ph.D. Economists, The Journal of Economic Education, 31:2, 191-201, DOI: 10.1080/00220480009596776

To link to this article: http://dx.doi.org/10.1080/00220480009596776

曲 Published online: 25 Mar 2010.

Submit your article to this journal $๘$

Џ Article views: 36

Q View related articles $\square$

4 Citing articles: 3 View citing articles 진 


\title{
Features and Information
}

In this section, the Journal of Economic Education publishes survey articles, international and institutional comparisons, and analytical studies on the economics curriculum, instructional materials, practices in teaching, and academic economics.

WILLIAM WALSTAD, Section Editor

\section{Interview Scheduling Strategies of New Ph.D. Economists}

\author{
John A. List
}

Given the importance of job placement for Ph.D.s, it is surprising that economists have not closely examined the factors that affect procuring job interviews for new Ph.D. economists. ${ }^{1}$ In this study, I investigated those factors using a data set gathered at the 1997 American Economic Association (AEA) meetings in New Orleans. My purpose was to increase the information available to $\mathrm{Ph}$.D. candidates who wish to maximize their postgraduation job prospects. In addition, this study may guide undergraduates and master's candidates who seek to pursue a Ph.D. in economics. The results of the findings, however, could benefit more than job seekers-they may provide academic departments and private industry with a comparative baseline for making decisions to interview job candidates.

The job market for new Ph.D.s consists of two submarkets-academic and business/industry. The following are questions regarding job seekers in both submarkets. (1) Do employers in academia seek the same attributes as business/industry? (2) Is there discrimination in the interview decision? (3) Is an MBA important in the Ph.D. market? (4) How many more interviews are secured by candidates with a finished dissertation? (5) How important are teaching and research credentials? (6) Are graduates from top-ranked programs given special consideration in the job market? (7) Do personal letters of recommendation or calls from professors make a difference in the interview decision? (8) How influ-

John A. List is an assistant professor of economics at the University of Central Florida (e-mail: John.List@bus.ucf.edu).The author wishes to thank Peter Kennedy, William Greene, Peter Orazem, William Becker, Debra Barbezat, Stephan Kroll, Craig Gallet, Mark Strazicich and five anonymous referees for useful comments. The author also thanks Jeff Petry, Josephine Stokes, and Jennifer List for valuable research assistance. The University of Central Florida provided financial support. 
ential are recommendation letters from prestigious economists? (9) What is the marginal effect of submitting another application?

A simple theoretic construct provides a basis for understanding the two-step job-search process carried out by new Ph.D. economists. ${ }^{2}$ In the first step, the job seeker decides whether to enter one or both submarkets and determines the optimal number of applications to submit. The second step reflects the actual decision process regarding acceptance or rejection of a job offer. Because a natural prerequisite to securing a job is an initial interview, my main focus in this study was to discover the optimal job search strategies for new Ph.D. economists by determining applicant characteristics that are conducive to obtaining interviews.

\section{THE DATA}

The market for beginning Ph.D. economists can be divided into three segments: (1) the preemptive market that compresses initial interviews, campus visits, and job offers into the time period prior to the annual January AEA meetings (e.g., the economist job market at smaller, regional meetings such as the Southern Economic Association meetings); (2) the primary market that takes place at the AEA annual meetings; and (3) the secondary market that extends from January until late May (Carson and Navarro 1988). Because 70 percent of jobs are advertised in the three-month period before the AEA meetings and because a majority of initial interviews for these positions are scheduled at the AEA meetings, I focused on the primary market.

Data were gathered by personal survey from a cohort of first-time job seekers at the 1997 AEA meetings in New Orleans. ${ }^{3}$ Participants in the survey typically were recruited by a monitor who approached a person attending the meetings and asked if he or she would like to participate in a survey that would take about five minutes. If the individual agreed, the monitor briefly explained the survey and usually worked one-on-one with the participant while he or she filled out the survey. ${ }^{4}$ A total of 222 participants gave usable information on items ranging from marital status to the number of initial interviews they had scheduled. ${ }^{5}$

The data in Table 1 indicate that the average survey participant had scheduled 5.99 academic interviews (denoted Academic), and 1.23 private business/industry interviews before he or she arrived in New Orleans. I analyzed only interviews that were scheduled prior to the meetings and not those obtained during the meetings. The data indicated that 60 percent of job seekers had 6 or fewer interviews in the academic market (Table 1). Analyses of the demographic variables indicated that men represented 71 percent of the sample (Male). Of the survey participants, 68 percent were white (White), and 66 percent were U.S. citizens. The average age of the participants was 32.04 (Age); 10 percent of those surveyed had a master's degree in business administration $(M B A)$; and the average survey participant had a 3.63 grade point average $(G P A){ }^{6}$

Those job searchers who were interviewed also provided information regarding an indicator of their teaching quality. The indicator, a measure of teaching quality, was awards or special recognition that the applicants had received for their classroom performance. Thirty (15 percent) applicants indicated that they 
had received an award or obtained special recognition for their teaching (Teach. Award). A job candidate's research credentials also represent a potentially important characteristic on the job market. The average job seeker had 0.74 published articles (\# Pubs.) and 0.1 top publications (\# Top Pubs.). A published article is considered a top publication if it is published in one of the top 36 economics journals, as ranked by Scott and Mitias (1996). ${ }^{7}$ In terms of unpublished research, the average survey participant had 0.26 paper submissions to the top 36 journals (\# Top Sub.) and 0.81 submissions (\# Sub.) to other refereed journals. These magnitudes are larger than the statistics reported by Barbezat (1992).

Ph.D. status may also be important on the job market. Thirty-one percent of those sampled said they had obtained an economics Ph.D. (Ph.D.) by January 2, 1997. This magnitude is again larger than Barbezat's sampled cohort and, combined with the above results, suggests that job seekers today are more apt to wait until they have significant credentials in the form of a completed Ph.D. or quality research before they test the job market.

Participants were also questioned about their institution of higher education. I used departmental rankings from Scott and Mitias to indicate institutional quality. The sample consisted of approximately 47 job seekers ( 21 percent) from each of the top 3 tiers and 82 ( 37 percent) from the lowest 140 ranked institutions. Given that the top 30 schools have historically produced almost half of all economics Ph.D.s (Stephens, Orazem, and Mattila 1994), candidates from lowerranked schools were oversampled; this may be a negative consequence of on-site survey administration.

Another potential indicator of interview counts is the special effort the candidate received from a mentor. Survey participants were asked whether an advisor, or anyone else, had made a phone call or written a personal letter on their behalf to potential employers. In the academic market (Extra-Academia) 45 percent of those surveyed indicated someone had done this for them, whereas 7 percent received extra help in the business/industry submarket (Extra-Bus/Ind). A further consideration was reference letters the candidates had received. Because reference letters from prestigious economists may be influential in the interview decision, I used the list of Hall of Fame Economists compiled by Scott and Mitias (1996) to account partly for the influence of reference letters. Scott and Mitias ranked 50 economists in terms of research produced in the top 5 and top 36 journals. Of those surveyed, 4 percent received reference letters from economists on one of these lists (HOF Ref.).

Employment preferences are another determinant of the interview outcome. Numerous indicators of applicant effort were gathered to control for job seeker preferences. The data indicated that the average job seeker submitted 40.87 applications to academic departments $[A p p($ Aca. $)]$ and 6.59 applications to business/industry $[A p p(B u s).]{ }^{8}$ Finally, because the bible of job announcements, AEA's Job Openings for Economists, indicates that opportunities for employment across fields of specialization are highly disparate, I included primary fields of study in the analysis. ${ }^{9}$ Approximately 20 percent of those surveyed had a field of specialization in growth/development, resource/environmental, econometrics/statistics, or industrial organization (Table 1). Fields that were less popular 
included comparative systems, history of economic thought, health economics, and welfare economics.

\section{EMPIRICAL METHODS}

To test for optimal job candidate signals, I assumed that the probability of obtaining an interview was a function of the job seeker's qualifications.

$$
\operatorname{Prob}\left(y_{i j}\right)=f\left(X_{i}\right) \text {, }
$$

where $y_{i j}$ represents the number of initial interviews job seeker $i$ obtained in submarket $j$ ( $j=$ academic, business/industry), and $X_{i}$ are the individual's attributes (Table 1). A common way to specify this type of discrete probability function is

TABLE 1

Descriptive Statistics

\begin{tabular}{|c|c|c|c|c|c|c|c|c|}
\hline \multirow[b]{2}{*}{ Interview } & & \multicolumn{2}{|c|}{ • } & \multicolumn{2}{|c|}{ Percentile } & \multirow[b]{2}{*}{$60 \mathrm{th}$} & \multirow[b]{2}{*}{80 th } & \multirow[b]{2}{*}{ Max. } \\
\hline & & Mean & Min. & 20 th & 40th & & & \\
\hline Academic & & $\begin{array}{c}5.99 \\
(6.62)\end{array}$ & $\begin{array}{c}0 \\
(51 \text { zeros })\end{array}$ & 0 & 2 & 6 & 10 & 35 \\
\hline Business/Industry & & $\begin{array}{c}1.23 \\
(2.37)\end{array}$ & $\begin{array}{c}0 \\
(140 \text { zeros })\end{array}$ & 0 & 0 & 0 & 2 & 20 \\
\hline $\begin{array}{l}\text { Exogenous } \\
\text { variable }\end{array}$ & Mean & Min. & Max. & $\begin{array}{l}\text { Exogenous } \\
\text { variable }\end{array}$ & & Mean & Min. & Max. \\
\hline Male & $\begin{array}{c}0.71 \\
(0.46)\end{array}$ & 0 & 1 & Ph.D. & & $\begin{array}{c}0.31 \\
(0.46)\end{array}$ & 0 & 1 \\
\hline White & $\begin{array}{c}0.68 \\
(0.47)\end{array}$ & 0 & 1 & Tier 1 & & $\begin{array}{c}0.23 \\
(0.42)\end{array}$ & 0 & 1 \\
\hline U.S. Citizen & $\begin{array}{c}0.66 \\
(0.48)\end{array}$ & 0 & 1 & Tier 2 & & $\begin{array}{c}0.21 \\
(0.41)\end{array}$ & 0 & 1 \\
\hline Age & $\begin{array}{l}32.04 \\
(5.21)\end{array}$ & 21 & 57 & Tier 3 & & $\begin{array}{c}0.21 \\
(0.41)\end{array}$ & 0 & 1 \\
\hline$M B A$ & $\begin{array}{c}0.10 \\
(0.31)\end{array}$ & 0 & 1 & Tier 4 & & $\begin{array}{c}0.35 \\
(0.48)\end{array}$ & 0 & 1 \\
\hline$G P A$ & $\begin{array}{c}3.63 \\
(0.23)\end{array}$ & 3 & 4 & $\begin{array}{l}\text { Extra help- } \\
\text { Academia }\end{array}$ & & $\begin{array}{c}0.45 \\
(0.50)\end{array}$ & 0 & 1 \\
\hline Teach. Award & $\begin{array}{c}0.15 \\
(0.35)\end{array}$ & 0 & 1 & $\begin{array}{l}\text { Extra help- } \\
\text { Bus/Ind }\end{array}$ & & $\begin{array}{c}0.07 \\
(0.26)\end{array}$ & 0 & 1 \\
\hline \# Pubs. & $\begin{array}{c}0.74 \\
(1.57)\end{array}$ & 0 & 11 & HOF Ref. & & $\begin{array}{c}0.04 \\
(0.20)\end{array}$ & 0 & 1 \\
\hline \# Top Pubs. & $\begin{array}{c}0.10 \\
(0.30)\end{array}$ & 0 & 1 & $A p p(A c a)$ & & $\begin{array}{c}40.87 \\
(31.64)\end{array}$ & 0 & 200 \\
\hline \# Sub. & $\begin{array}{c}0.81 \\
(1.2)\end{array}$ & 0 & 8 & $A p p(B u s)$. & & $\begin{array}{c}6.59 \\
(16.25)\end{array}$ & 0 & 200 \\
\hline \# Top Sub. & $\begin{array}{c}0.26 \\
(0.44)\end{array}$ & 0 & 3 & App(Govt.) & & $\begin{array}{c}2.53 \\
(4.45)\end{array}$ & 0 & 50 \\
\hline
\end{tabular}


TABLE 1-Continued

\begin{tabular}{|c|c|c|c|c|c|c|c|}
\hline Field & Mean & Min. & Max. & Field & Mean & Min. & Max. \\
\hline $\begin{array}{l}\text { Comparative } \\
\text { systems }\end{array}$ & $\begin{array}{c}0.05 \\
(0.21)\end{array}$ & 0 & 1 & $\begin{array}{l}\text { Econometrics/ } \\
\text { Statistics }\end{array}$ & $\begin{array}{c}0.18 \\
(0.39)\end{array}$ & 0 & 1 \\
\hline $\begin{array}{l}\text { Growth and } \\
\text { development }\end{array}$ & $\begin{array}{c}0.18 \\
(0.39)\end{array}$ & 0 & 1 & Health & $\begin{array}{c}0.05 \\
(0.23)\end{array}$ & 0 & 1 \\
\hline History & $\begin{array}{c}0.02 \\
(0.15)\end{array}$ & 0 & 1 & $\begin{array}{l}\text { Industrial } \\
\text { Organization }\end{array}$ & $\begin{array}{c}0.19 \\
(0.39)\end{array}$ & 0 & 1 \\
\hline $\begin{array}{l}\text { International } \\
\text { finance }\end{array}$ & $\begin{array}{c}0.14 \\
(0.35)\end{array}$ & 0 & 1 & $\begin{array}{l}\text { International } \\
\text { Trade }\end{array}$ & $\begin{array}{c}0.16 \\
(0.37)\end{array}$ & 0 & 1 \\
\hline Labor & $\begin{array}{c}0.16 \\
(0.37)\end{array}$ & 0 & 1 & Macro. Theory & $\begin{array}{c}0.15 \\
(0.36)\end{array}$ & 0 & 1 \\
\hline Managerial & $\begin{array}{c}0.05 \\
(0.22)\end{array}$ & 0 & 1 & Math Econ. & $\begin{array}{c}0.05 \\
(0.23)\end{array}$ & 0 & 1 \\
\hline Micro. theory & $\begin{array}{c}0.14 \\
(0.34)\end{array}$ & 0 & 1 & Monetary & $\begin{array}{c}0.09 \\
(0.29)\end{array}$ & 0 & 1 \\
\hline Public finance & $\begin{array}{c}0.16 \\
(0.37)\end{array}$ & 0 & 1 & $\begin{array}{l}\text { Regional/ } \\
\text { Urban }\end{array}$ & $\begin{array}{c}0.06 \\
(0.24)\end{array}$ & 0 & 1 \\
\hline $\begin{array}{l}\text { Resource/ } \\
\text { environment }\end{array}$ & $\begin{array}{c}0.19 \\
(0.39)\end{array}$ & $\begin{array}{l}0 \\
0\end{array}$ & $\begin{array}{l}1 \\
1\end{array}$ & Welfare & $\begin{array}{c}0.03 \\
(0.18)\end{array}$ & 0 & 1 \\
\hline
\end{tabular}

Note: Standard deviations are in parentheses

as a Poisson process, which models the expected number of interviews as $E(y)=$ $e^{X b}$, where $\boldsymbol{X}$ is the regressor vector, and $b$ are the response coefficients of interest.

An important concern in the estimation of equation (1) is that the number of occurrences of zero interviews in submarket $j$ exceeds what the Poisson model would predict. The data in Table 1 indicate that 51 job seekers had zero interviews in the academic submarket ( 23 percent), and 140 job seekers had zero interviews in the business/industry submarket ( 63 percent). A zero interview occurrence in submarket $j$ could arise from a variety of reasons, such as carrying out a limited search, inferior teaching and research experience, or the underlying data generation process. Those respondents who submitted zero applications in a particular submarket were considered to be out of the market and not included in the analysis. After deletions, the sample consisted of $n=211$ (academic) and $n=119$ (business/industry) observations. Nevertheless, data from these job seekers suggested that there remained a potential excess-zero problem, as 41 ( $\approx 20$ percent) and 37 ( $\approx 31$ percent) job seekers obtained zero interviews in the academic and business/industry submarkets, respectively.

A technique to account for this potential excess-zero problem is discussed in Greene (1994). The procedure is a two-step estimation process and has been given a variety of names, including zero-inflated Poisson (ZIP), zero-altered Poisson (ZAP), hurdle model, or with zero's (WZ) model. When estimating such models, it is important to include variables in stage 1 that signal job seeker preferences for gainful employment in a submarket. Because considerable information is contained in the job seeker's behavior, one important explanatory variable 
was included in the first estimation stage-applications submitted to submarket $j$. Use of this variable is justified for numerous reasons. For example, if a job seeker cares little about obtaining employment in a submarket, he or she will send few applications to that submarket because of the positive opportunity cost associated with each application. Hence, in the zero-inflated model, some job seekers will not clear the initial hurdle and thus will be predicted to have zero initial interviews in that particular submarket. ${ }^{10}$

\section{RESULTS AND DISCUSSION}

Second stage estimation results for the academic and business/industry job markets are shown in Tables 2 and 3. ${ }^{11}$ A preliminary concern was the possible heterogeneity in the interview decision across the two submarkets. A likelihood ratio test indicated prospective employers across submarkets considered individual attributes differently when making the interview decision. This result implied that a unique specification was appropriate for each submarket. ${ }^{12}$

I employed the ZIP model for estimates for the academic market because the level of the Vuong statistic $(V)$ in column 6 of Table 2 suggested the zero-inflat-

TABLE 2

Parameter Estimates for the Academic Market

\begin{tabular}{|c|c|c|c|c|c|}
\hline \multicolumn{6}{|c|}{ Zero-Inflated Poisson Model } \\
\hline $\begin{array}{l}\text { Independent } \\
\text { variable }\end{array}$ & $\begin{array}{l}\text { Marginal } \\
\text { effect }\end{array}$ & $\begin{array}{l}\text { Independent } \\
\text { variable }\end{array}$ & $\begin{array}{c}\text { Marginal } \\
\text { effect }\end{array}$ & $\begin{array}{c}\text { Independent } \\
\text { variable }\end{array}$ & $\begin{array}{c}\text { Marginal } \\
\text { effect }\end{array}$ \\
\hline Male & $\begin{array}{r}-0.86 \\
(.01)\end{array}$ & \# Top Sub. & $\begin{array}{l}1.13 \\
(.01)\end{array}$ & $\begin{array}{l}\text { Growth and } \\
\text { development }\end{array}$ & $\begin{array}{r}-1.44 \\
(.01)\end{array}$ \\
\hline White & $\begin{array}{r}-0.06 \\
(.83)\end{array}$ & Ph.D. & $\begin{array}{l}0.64 \\
(.04)\end{array}$ & Public finance & $\begin{array}{r}-1.69 \\
(.01)\end{array}$ \\
\hline U.S. Citizen & $\begin{array}{l}0.14 \\
(.49)\end{array}$ & Tier 2 & $\begin{array}{r}-1.27 \\
(.01)\end{array}$ & & \\
\hline Age & $\begin{array}{r}-0.24 \\
(.01)\end{array}$ & Tier 3 & $\begin{array}{r}-1.07 \\
(.01)\end{array}$ & & \\
\hline$M B A$ & $\begin{array}{r}-0.03 \\
(.96)\end{array}$ & Tier 4 & $\begin{array}{r}-1.60 \\
(.01)\end{array}$ & $\begin{array}{l}\text { Diagnostics } \\
V^{a}\end{array}$ & 4.54 \\
\hline$G P A$ & $\begin{array}{l}2.50 \\
(.01)\end{array}$ & Extra help & $\begin{array}{l}1.37 \\
(.01)\end{array}$ & $\begin{array}{l}\text { Loglike } \\
n\end{array}$ & $\begin{array}{r}-679 \\
211\end{array}$ \\
\hline Teach. Award & $\begin{array}{l}0.83 \\
(.02)\end{array}$ & HOF Ref. & $\begin{array}{l}2.92 \\
(.01)\end{array}$ & & \\
\hline \# Pubs. & $\begin{array}{l}0.25 \\
(.01)\end{array}$ & App(Aca.) & $\begin{array}{l}0.07 \\
(.01)\end{array}$ & & \\
\hline \# Top Pubs. & $\begin{array}{l}3.68 \\
(.01)\end{array}$ & $A p p(B u s)$. & $\begin{array}{r}-0.07 \\
(.01)\end{array}$ & & \\
\hline \# Sub. & $\begin{array}{l}0.29 \\
(.04)\end{array}$ & App (Govt.) & $\begin{array}{r}-0.06 \\
(.05)\end{array}$ & & \\
\hline
\end{tabular}

Notes: $p$ ratios are in parentheses; $p$ values $<.01$ are rounded to .01 . Coefficient estimates for fields of specialization are included only when they are significant.

${ }^{\mathrm{a}} V$ represents the Vuong statistic. 
TABLE 3

Parameter Estimates for the Business/Industry Market

\begin{tabular}{|c|c|c|c|c|c|}
\hline \multicolumn{6}{|c|}{ Standard Poisson Model } \\
\hline $\begin{array}{l}\text { Independent } \\
\text { variable }\end{array}$ & $\begin{array}{c}\text { Marginal } \\
\text { effect }\end{array}$ & $\begin{array}{c}\text { Independent } \\
\text { variable }\end{array}$ & $\begin{array}{c}\text { Marginal } \\
\text { effect }\end{array}$ & $\begin{array}{c}\text { Independent } \\
\text { variable }\end{array}$ & $\begin{array}{c}\text { Marginal } \\
\text { effect }\end{array}$ \\
\hline Male & $\begin{array}{l}1.25 \\
(.01)\end{array}$ & \# Top Sub. & $\begin{array}{l}0.27 \\
(.01)\end{array}$ & $\begin{array}{l}\text { Diagnostics } \\
V\end{array}$ & 1.87 \\
\hline White & $\begin{array}{l}0.63 \\
(.31)\end{array}$ & Ph.D. & $\begin{array}{l}1.11 \\
(.10)\end{array}$ & $\begin{array}{l}\text { Loglike. } \\
n\end{array}$ & $\begin{array}{c}197 \\
119\end{array}$ \\
\hline U.S. Citizen & $\begin{array}{r}-0.49 \\
(.42)\end{array}$ & Tier 2 & $\begin{array}{r}-0.57 \\
(.41)\end{array}$ & & \\
\hline Age & $\begin{array}{r}-0.14 \\
(.05)\end{array}$ & Tier 3 & $\begin{array}{r}-2.60 \\
(.03)\end{array}$ & & \\
\hline$M B A$ & $\begin{array}{l}1.41 \\
(.19)\end{array}$ & Tier 4 & $\begin{array}{r}-1.46 \\
(.08)\end{array}$ & & \\
\hline$G P A$ & $\begin{array}{l}0.68 \\
(.52)\end{array}$ & Extra help & $\begin{array}{l}3.22 \\
(.02)\end{array}$ & & \\
\hline Teach. Award & $\begin{array}{l}0.80 \\
(.27)\end{array}$ & HOF Ref. & $\begin{array}{r}-0.70 \\
(.62)\end{array}$ & & \\
\hline \# Pubs. & $\begin{array}{l}0.19 \\
(.48)\end{array}$ & $A p p(A c a)$. & $\begin{array}{l}0.01 \\
(.45)\end{array}$ & & \\
\hline \# Top Pubs. & $\begin{array}{l}0.37 \\
(.74)\end{array}$ & App (Bus.) & $\begin{array}{l}0.02 \\
(.12)\end{array}$ & & \\
\hline \# Sub. & $\begin{array}{r}-0.04 \\
(.88)\end{array}$ & App (Govt.) & $\begin{array}{l}0.08 \\
(.09)\end{array}$ & & \\
\hline
\end{tabular}

Notes: $p$ ratios are in parentheses; $p$ values $<.01$ are rounded to .01 . Coefficient estimates for fields of specialization are included only when they are significant.

ed model was more appropriate than the unaugmented model. Coefficient estimates in Table 2 are derivatives of the conditional mean function with respect to the attribute vector $\left[d E(y \mid x) / d x=e^{X b} b\right]$ measured at the overall sample means. ${ }^{13}$ Marginal effects estimates on the demographic variables indicated gender was considered when interviews were scheduled. The model suggested that women obtained 0.86 more interviews than men, ceteris paribus, which was significant at the $p=.01$ level. Although seemingly trivial, given that the mean number of academic interviews was 5.75 , an expected increase of 0.86 was substantial for the average candidate. There was also evidence that older candidates received fewer academic interviews than younger candidates-each additional year in age lowered expected interview counts by 0.24 .

Although these personal traits are important, candidates may be more interested in factors they can control. For example, often first-year job seekers question the importance of teaching credentials and GPA. Estimates from the regression model indicated that a candidate's teaching portfolio was highly influential in the academic market. Coefficient estimates suggested that job seekers who earned a teaching award also received special recognition on the academic job market, as 0.83 more interviews were garnered by award-winning candidates. Also, empirical results implied that a one standard deviation increase (about 
0.23 ) in GPA increased the expected count of interviews by more than 0.57 .

Coefficient estimates on the research variables were also intuitively appealing. Results implied that academic departments desired candidates who had published in refereed journals, particularly job seekers with publications in the top 36 journals. For instance, each peer-reviewed article in a highly rated journal yielded approximately 3.68 academic interviews. Estimates also suggested that research activity, in itself, was important-submission of research papers to refereed journals significantly increased the expected count of interviews.

Other important considerations were $\mathrm{Ph} . \mathrm{D}$. status and perceived quality of the doctoral-granting institution. Coefficient estimates indicate that Ph.D. status was instrumental in the interview decision as Ph.D.s received 0.64 more academic interviews than $\mathrm{ABDs}$ (all but degrees). Estimates also suggested that there were some institutions that were clearly considered the best (top 19) and a group considered the rest (institutions ranked 20 to 240 ). Ninety-five percent confidence intervals indicated that interview outcomes were not significantly different across schools ranked 20 to 240 . Nevertheless, estimates suggested a substantial difference existed between the top schools and the others, as a job candidate from a top-19 institution received approximately 1 to 1.6 more academic interviews than a job seeker from a tier 2 to 4 school ranked 20 to 240 .

Reference letters from prestigious economists also significantly affected the interview decision. Parameter estimates suggested that considerably more academic interviews were obtained by candidates with a letter of recommendation written by a Hall of Fame economist. This finding indicated that academic search committees were highly influenced by recommendation letters from top economists, suggesting candidates can significantly improve their chances on the academic market if they work with eminent scholars and obtain letters of recommendation from them. Candidates were also buoyed by the extra help they received on the academic job market. The academic marketplace remains a world of networking.

Parameter estimates in Table 2 also suggest that the number of applications submitted to academia significantly affected the number of interviews secured. A parameter estimate of 0.07 provided an indication of the marginal effect of sending out one more application-at the mean, another submitted application increased the expected number of interviews by 0.07 . Other coefficient estimates suggested that candidates used submarkets as substitutes. Applications to other popular submarkets, business/industry and government, significantly decreased the number of academic interviews secured. Fields of study that were unattractive included growth and development and public finance. ${ }^{14}$

Empirical results for the business/industry submarket (Table 3) were obtained with the standard Poisson model. I found that the augmented model was unnecessary-the Vuong statistic did not present compelling evidence in favor of the zero-inflated model ( $V=1.87$ ). Marginal effects in Table 3 suggest that a degree of discrimination also exists in the business/industry market. At the $p<.12$ level, women received 1.25 fewer interviews than men. In addition, older job seekers expected fewer interviews than their younger counterparts, at a rate of 0.14 interviews per added year. Other coefficient estimates indicated that a finished dis- 
sertation was a major asset on the private market as ABDs received approximately 1.11 fewer interviews than those candidates with a Ph.D. in hand, which was significant at the $p=.10$ level.

Employers in business/industry, like academicians, also separated schools into tiers when scheduling interviews. Business/industry, however, had a much larger range of acceptable schools; they preferred the top 49 schools over those ranked 50 to 240 . Estimates implied that job seekers from the top 19 institutions had approximately $0.5-2.6$ more interviews than comparable candidates from lower tier schools. Interestingly, letters of recommendation from prestigious economists were not appealing to employers in business/industry. Extra help, however, on behalf of the candidate by a mentor or someone else, was a major asset on the private market as parameter estimates indicated that substantially more interviews were secured when extra help was received.

Other parameter estimates indicated that the number of applications submitted to the private industry significantly affected the number of interviews secured at the $p=.12$ level. A parameter estimate of 0.02 suggested that each submitted application increased the expected number of interviews by roughly 0.02 .

\section{CONCLUDING REMARKS}

Estimation results suggested a heterogeneity in the interview decision across submarkets. For example, employers in academia favored candidates who had quality research publications, a completed Ph.D. from a top 19 institution, and references from established scholars. On the other hand, business/industry employers sought candidates with completed Ph.D.s from a top 49 institution. Both submarkets displayed a degree of discrimination in the interview decision: Age and gender significantly affected candidates' interview counts.

Conclusions from this study provide a basis for possible future research avenues. Given the finding that a degree of discrimination across submarkets exists, it would be interesting to focus on the effects of discrimination on job seekers' search decisions. For example, do female job searchers pursue employment opportunities in academia rather than in private industry because of perceived inequities? Although the econometric specifications partially control for search effort by including the number of applications to each submarket, it would be worthwhile to delve further into this issue by making the search decision endogenous. Finally, it would be interesting to know how interview decisions have changed in recent years. In this survey, I covered a period characterized by relatively low demand for new Ph.D.s. An interesting extension would be to link these results with past findings from stronger job markets and compare the magnitudes and signs of estimated coefficients.

\section{NOTES}

1. Two exceptions are the studies of Carson and Navarro (1988; 1985-86 cohort) and Barbezat (1992; 1988-89 cohort).

2. See Stephens, Orazem, and Mattila (1994) for a derivation of search in a multimarket model. I have also developed a model of multimarket search. Further information can be obtained upon request. 
3. To maintain consistency with prior studies, I focused on candidates who were entering the Ph.D. job market for the first time, thus avoiding any biases associated with including repeat searchers.

4. A copy of the survey instrument may be obtained from the author.

5. Gathering data onsite has both advantages and disadvantages. A potential disadvantage is that only job seekers who have interviews scheduled in advance attend the meetings. Another potential disadvantage of this particular on-site data-generating process is that highly sought-aftercandidates may not have the same probability of being surveyed as lower echelon job seekers because of tight interview schedules. On the other hand, a potential advantage of on-site surveys is that possible sample selection bias may be mitigated. Previous studies of the economist job market have gathered data by mail surveys, after the primary market has cleared. Because only successful job seekers may be responding to mail surveys, the lower end of the job probability distribution may not be collected.

6. The survey data on gender, race/ethnicity, citizenship, and GPA were relatively close to averages from National Research Council (1995) data.

7. This ranking system had notable shortcomings. For example, the list was constructed without a quantitative basis, lending an ad hoc nature to the ranking. For a clear exposition of other important methodology problems, see Becker (1997).

8. Because the number of applications submitted to the government submarket was used in the regression equations, I included descriptive statistics for the number of applications submitted to local, state, and federal government $[A p p($ Govt. $)]$.

9. For example, according to the "Report of the Director," American Economic Review Papers and Proceedings $(1997,498)$, of the 2,431 available positions listed in Job Openings for Economists in 1996, international economics, macroeconomics, industrial organization, and economic history were fields cited in 10.4 percent, 11 percent, 8.8 percent, and 0.9 percent, respectively, of advertised positions. Note, however, that a single job is often advertised for more than one field.

10. A final nuance of zero-inflated models is that the changed probability induces a divergence between the mean and variance of the distribution, even in the absence of heterogeneity. As such, zero-inflated models induce overdispersion; the more likely the zero state, the greater is the overdispersion. Vuong (1989) has proposed a test statistic for nonnested models that has desired statistical properties. The Vuong statistic $(V)$ is directional. If $\mid V<1.96$, the test supports neither model (e.g., ZIP versus Poisson). If the test statistic is positive and larger than 1.96, then the zeroinflated model is favored. Very negative values support the unaugmented or standard models.

11. The number of interviews each candidate potentially secures has an upper bound because time could represent a constraint (the AEA meetings last only four days). This manifests as an upper truncation of the dependent variable (number of interviews). Both submarket regressions were also run, accounting for truncation at a value equal to 35. Parameter estimates from the truncated regressions mirror those in Tables 2 and 3 . Nevertheless, to control for the possibility that time could be a constraint, or that, for example, interviews in business/industry were crowded out by interviews in other popular submarkets (such as academia and government), I included the number of applications to submarkets $i$ and $k$ as exogenous variables in the regression for submarket $j$. Estimation results from the first stage are available from the author.

12. Upon the request of a reviewer, I used a likelihood ratio test to test down to a parsimonious specification that excluded insignificant variables from the regression. Because these new sets of regressions yielded coefficient estimates on the significant variables very similar to those in the full version, I only present the full-model results.

13. Non-White and Tier 1 are omitted categories and therefore represent baseline comparisons.

14. I initially included all 18 fields of specialization dummy variables in the estimated regression; only fields with significant coefficient estimates were included in the final specification. In addition, I originally estimated the model with an indicator of teaching experience and Black, Hispanic, Asian, and Other race dummies. Given that these variables were consistently insignificant, they were excluded from the final specification. Their inclusion did not markedly change the results. I also followed this procedure in the Business/Industry specification.

\section{REFERENCES}

Barbezat, D. 1992. The market for new Ph.D. economists. Journal of Economic Education 23 (Summer): 262-76.

Becker, W. 1997. Economics, education, and economists: A view from the United States. Australian Economic Papers (Sept.): 5-16.

Carson, R., and P. Navarro, 1988. A seller's (\& buyer's) guide to the job market for beginning academic economists. Journal of Economic Perspectives 2 (Spring): 137-48. 
Greene, W. 1994. Accounting for excess zeros and sample selection in Poisson and negative binomial regression models. Working paper \# EC-94-10. New York University.

National Research Council, Office of Scientific Engineering Personnel. 1996. Summary report 1995; Doctorate recipients from United States universities. Washington, D.C.: National Academy Press. Report of the Director. 1997. American Economic Review Papers and Proceedings 87 (2): 497-98.

Scott, L., and P. Mitias. 1996. Trends in rankings of economics departments in the U.S.: An update. Economic Inquiry 34 (April): 378-400.

Stephens, K., P. Orazem, and P. Mattila. 1994. Job search strategies and outcomes in the market for new Ph.D. economists. Working paper. lowa State University.

Vuong, Q. 1989. Likelihood ratio tests for model selection and non-nested hypotheses. Econometrica 57 (2): 307-34.

\section{STUDENTS SOLVE ECONOMIC MYSTERIES with CAPSTONE}

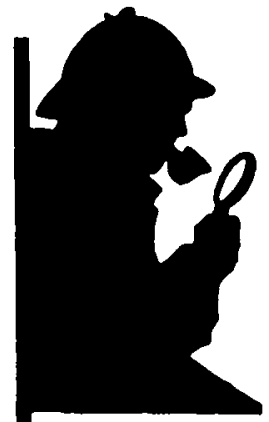

Mail coupon to: NATIONAL COUNCIL ON ECONOMIC EDUCATION/MARKETING Dept. 1140 AVENUE OF THE AMERICAS, NEW YORK, NY 10036

Please send the complete CAPSTONE teaching package: Teacher Resource Manual and Student Activities Book plus a bonus sel of resource materials-all in a convenient storage box. I understand the National Council will bill me for $\$ 119.95$, plus shipping and handling.

Name

Position

School

Street Address

City, State, Zip

(must be included)

Purchase Order No.:

Date:

School Telephone No.: 